\title{
Flow-cytometry as an auxiliary in the diagnosis of primary humoral immunodeficiencies
}

\author{
Leopoldo Santos-Argumedo, ${ }^{*}$ Laura Berrón-Ruiz, Gabriela López-Herrera and \\ Nidia Carolina Moreno-Corona \\ Instituto Politécnico Nacional, Center of Research and Advanced Studies, Department of Molecular Biomedicine, Mexico City, Mexico
}

\begin{abstract}
Background: Antibody deficiencies encompass a wide spectrum of pathologies and constitute approximately $50 \%$ of primary immunodeficiencies; with cytometry, it is possible to evaluate the immune status rapidly, effectively and at low cost. Objective: To assess, by means of flow cytometry, the cells of patients with three types of primary humoral immunodeficiencies. Method: Using flow cytometry, blood samples from patients and healthy subjects were analyzed with different monoclonal antibodies. Results: Using various stains, a severe decrease in B lymphocytes was shown in patients with X-linked agammaglobulinemia, as well as a lack of CD154 expression in patients with hyper-immunoglobulin M syndrome, and heterogeneity of B lymphocyte subpopulations in patients with common variable immunodeficiency. Conclusion: Flow cytometry enables early diagnosis of primary immunodeficiencies with a high level of confidence and, in many cases, identification of the genes involved.
\end{abstract}

KEY WORDS: Agammaglobulinemia. Hyper-immunoglobulin M. Common variable immunodeficiency.

\section{La citometría de flujo como auxiliar en el diagnóstico de las inmunodeficiencias primarias humorales}

\section{Resumen}

Antecedentes: Las deficiencias de anticuerpos abarcan un amplio espectro de patologías y constituyen aproximadamente 50 $\%$ de las inmunodeficiencias primarias; con la citometría es posible evaluar el estado inmunológico de forma rápida, efectiva y a bajo costo. Objetivo: Evaluar mediante citometría de flujo, las células de pacientes con tres tipos de inmunodeficiencias primarias humorales. Método: Mediante citometría de flujo se analizaron muestras de sangre de pacientes y sujetos sanos con distintos anticuerpos monoclonales. Resultados: Mediante diversas tinciones se demostró disminución severa de linfocitos $B$ en pacientes con agammaglobulinemia ligada al cromosoma X, la falta de expresión de CD154 en pacientes con síndrome de hiperinmunoglobulina $M$ y heterogeneidad de subpoblaciones de linfocitos $B$ en pacientes con inmunodeficiencia común variable. Conclusión: Con la citometría de flujo es posible realizar el diagnóstico temprano de inmunodeficiencias primarias con un nivel de confianza elevado y, en muchos casos, identificar los genes implicados.

PALABRAS CLAVE: Agammaglobulinemia. Hiperinmunoglobulina M. Inmunodeficiencia común variable.

Correspondence:

*Leopoldo Santos-Argumedo

E-mail: lesantos@ cinvestav.mx
Gac Med Mex. 2020;156:194-200

Contents available at PubMed

www.gacetamedicademexico.com

0016-3813/@ 2020 Academia Nacional de Medicina de México, A.C.. Published by Permanyer. This is an open access article under the CC BY-NC-ND license (http://creativecommons.org/licenses/by-nc-nd/4.0/). 
Table 1. Classification of predominantly antibody immunodeficiencies*

\begin{tabular}{|c|c|c|c|c|}
\hline Disease & Serum lg & Characteristics & Type of inheritance & Genetic defects \\
\hline $\begin{array}{l}\text { X chromosome-linked } \\
\text { agammaglobulinemia }\end{array}$ & All isotypes decreased & $\begin{array}{l}\text { Serious bacterial infections. } \\
\text { Absence or highly significant } \\
\text { decrease of mature B cells }\end{array}$ & X chromosome-linked & Mutations in BTK \\
\hline $\begin{array}{l}\text { Autosomal recessive } \\
\text { agammaglobulinemia }\end{array}$ & All isotypes decreased & $\begin{array}{l}\text { Serious bacterial infections. } \\
\text { Absence or highly significant } \\
\text { decrease of mature B cells }\end{array}$ & Autosomal recessive & $\begin{array}{l}\text { Mutations in } \mu \text { heavy } \\
\text { chain, in } 15, \lg \alpha, \lg \beta \\
\text { and BLNK }\end{array}$ \\
\hline $\begin{array}{l}\text { Common variable } \\
\text { immunodeficiency }\end{array}$ & $\begin{array}{l}\text { Decreased IgG, IgA } \\
\text { and/or IgM }\end{array}$ & $\begin{array}{l}\text { Recurrent bacterial infections, } \\
\text { some patients experience } \\
\text { autoimmunity, lymphoproliferation } \\
\text { or granulomatous disease }\end{array}$ & Variable & $\begin{array}{l}\text { Mostly unknown, } \\
\text { in some cases, } \\
\text { mutations in ICOS, } \\
\text { CD19, TACI, BAFF-R }\end{array}$ \\
\hline Hyper-IgM syndrome & $\begin{array}{l}\text { Normal or elevated } \\
\text { IgM with decreased } \\
\lg A \text { and IgG }\end{array}$ & $\begin{array}{l}\text { Opportunistic infections, } \\
\text { neutropenia, autoimmune } \\
\text { diseases }\end{array}$ & $\begin{array}{l}X \text { chromosome-linked } \\
\text { (CD154) or autosomal } \\
\text { recessive }\end{array}$ & $\begin{array}{l}\text { Mutations in CD154, } \\
\text { CD40, AICDA, UNG }\end{array}$ \\
\hline $\begin{array}{l}\text { Isotype deficiencies with B } \\
\text { cell normal numbers }\end{array}$ & $\begin{array}{l}\text { One or more lgG } \\
\text { and/or lgA and lgE } \\
\text { subclasses decreased }\end{array}$ & $\begin{array}{l}\text { Asymptomatic in some cases, or } \\
\text { subjects can experience recurrent } \\
\text { bacterial and viral infections }\end{array}$ & Variable & $\begin{array}{l}\text { Mutations or } \\
\text { deletions in } \\
\text { chromosome } 14 q 32 \\
\text { or in } \lambda \text { light chain }\end{array}$ \\
\hline $\begin{array}{l}\text { Antibody-specific deficiency } \\
\text { with normal concentrations of } \\
\text { Ig and B cells }\end{array}$ & Normal & $\begin{array}{l}\text { Inability to produce antibodies } \\
\text { against some specific antigens }\end{array}$ & Variable & Unknown \\
\hline $\begin{array}{l}\text { Transient } \\
\text { hypogammaglobulinemia of } \\
\text { infancy }\end{array}$ & $\begin{array}{l}\text { Decreased } \lg G \text { and } \\
\lg A\end{array}$ & $\begin{array}{l}\text { Moderate to recurrent bacterial } \\
\text { infections }\end{array}$ & Variable & Unknown \\
\hline
\end{tabular}

\section{Introduction}

Primary immunodeficiencies (PID) are genetic conditions that lead to susceptibility to infections by germs that generally are poorly virulent. PIDs can be inherited or acquired by de novo mutations during embryonic development. ${ }^{1}$ In Mexico, no reliable statistics regarding the magnitude of the problem are available. Due to the lack of appropriate methods, PIDs are not diagnosed in most cases. More than 180 conditions have been identified in the world thanks to the development of high-impact analysis tools, such as flow cytometry, which is combined with molecular diagnosis. ${ }^{2}$ In the PID classification accepted by the International Union of Immunology Societies, various conditions are recognized, among which defects in antibody production are the most common. ${ }^{2}$ In the European Society of Immunodeficiencies statistics ${ }^{3}$ and in various publications of the United States, defects in the production of antibodies comprise about half the diagnosed cases. Mexico ranks third in Latin America in recorded PID cases; according to data from the Latin American Society of Immunodeficiencies, at least one in 200 to 500 children has an antibody PID. ${ }^{4}$ Notwithstanding the foregoing, the region is still far from having real statistics

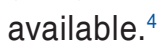

Antibody deficiencies encompass a wide spectrum of pathologies, from severe insufficiency in the production of all immunoglobulin isotypes and total $a b$ sence of mature $B$ lymphocytes, to selective deficiency of one isotype (Table 1). ${ }^{5}$ Patients with these deficiencies show no signs of disease during the first months of life, due to the antibodies they receive from the mother; however, the number and severity of infections increases when those antibodies decrease. Regular administration of human gamma-globulin can prevent progressive deterioration and allows patients to lead almost normal lives, as long as therapeutic interventions are carried out at an early age, which is why early diagnosis is essential. ${ }^{6}$ Flow cytometry enables making early diagnoses with a high level of reliability and, in many cases, investigating genes with possible defects.? 
In this work, we show the assessment of patients with defects in the production of antibodies by using simple and rapid stains; the comparison was established with healthy individuals (control group).

\section{Method}

Cross-sectional, prospective, descriptive study. Children previously diagnosed at the National Institute of Pediatrics or at La Raza National Medical Center of the Mexican Institute of Social Security, Mexico City, with X-linked agammaglobulinemia $(X L A)$, hyperimmunoglobulinemia $M$ syndrome (hyper-IgM syndrome) or common variable immunodeficiency (CVID), according to the criteria established for PIDs, were included. ${ }^{8}$ Parents or legal guardians granted their consent after being informed on the purposes and procedures of the investigation (in accordance with the ethical principles established in the Declaration of Helsinki). Patients with secondary causes of hypo- or agammaglobulinemia were excluded $^{8}$, and patients with insufficient samples or who decided to withdraw from the investigation were censored.

Three to $10 \mathrm{~mL}$ of peripheral blood were obtained, with heparinized Vacutainer ${ }^{\circledR}$ tubes (Becton Dickinson, San Jose, CA, USA); $1 \mathrm{~mL}$ was used to determine leukocyte populations and the rest was used to obtain mononuclear cells by centrifugation in Histopaque ${ }^{\circledR}$ (Sigma, Chemical Co., St Louis, MO, USA).

By means of staining, the percentages of the different cell populations were determined. $30 \mu \mathrm{L}$ of non-activated peripheral blood were used and incubated for 20 minutes with $5 \mu \mathrm{L}$ of the following monoclonal antibody mixtures:

- Anti-CD45-FITC/anti-CD14-PE.

- Anti-CD3 FITC/anti-CD19 PE/anti-CD45 PerCP.

- Anti-CD4 FITC/anti-CD8 PE/anti-CD3 PerCP.

- Anti-CD3 FITC/anti-CD16+56 PE/anti-CD45 PerCP.

Anti-CD45 PerCP/ $\gamma 1$ FITC/ $\gamma 1$ PE was used as isotype control antibodies. Most antibodies used were obtained from Becton Dickinson; otherwise, the laboratory of origin is indicated. The samples were incubated 20 minutes at room temperature, in the dark. After incubation, the erythrocytes were lysed with 500 $\mu \mathrm{L}$ of $\mathrm{FACS}^{\circledR}$ lysis solution (Becton, Dickinson, San Jose, CA, USA), incubated for an additional $10 \mathrm{~min}$ utes, and then washed with phosphate buffered saline (PBS) and $1 \%$ human serum albumin. The cells were fixed with $1 \%$ formaldehyde in PBS. The acquisition and analysis will be described later on.
B cell subpopulations were determined from mononuclear cells, which were stained with the anti-CD27 PE/anti-CD19 APC/anti-IgD FITC and anti-CD24 PE/anti-CD38 APC/anti-CD19 FITC mixtures; incubation, washing and fixation were carried out as described and erythrocyte lysis was omitted.

\section{Bruton's tyrosine kinase expression determination}

One million mononuclear cells were fixed with $1 \%$ formaldehyde in PBS for 10 minutes. The mononuclear cells were washed with PBS with $10 \%$ of human serum albu$\min$ at $300 \times \mathrm{g}$ for five minutes and permeabilized for 10 minutes with $0.1 \%$ saponin in PBS (PBS-S). Labeling was carried out with $30 \mu \mathrm{L}$ of the anti-Btk monoclonal antibody (Bruton's tyrosine kinase, Pharmingen, San Diego, CA, USA), followed by 30 minutes of incubation and two washes with PBS-S. Staining was carried out with $30 \mu \mathrm{L}$ of anti-IgG2a PE (Upstate Biotechnology, Lake Placid, NY, USA) and the cells were then incubated for 30 minutes in the dark. Subsequently, the cells were washed with PBS-S, stained with $5 \mu \mathrm{L}$ of anti-CD14 FITC and incubated for 15 minutes in the dark; finally they were washed and fixed with $300 \mu \mathrm{L}$ of $1 \%$ formaldehyde in PBS.

\section{$C D 40$ and $T A C l$ expression determination}

The mononuclear cells were incubated with anti-CD40 PE and anti-CD19 APC to identify their expression in $\mathrm{B}$ cells, and with anti-CD40 PE and anti-CD14 PerCP to identify their expression in monocytes. In another tube, the mononuclear cells were incubated with anti-TACI PE and anti-CD22 PECy5. Incubation, washing and fixation were carried out according to the described procedures.

\section{CD154 and ICOS expression determination}

For the determination of CD154, two million mononuclear cells were cultivated for 12 hours at $37^{\circ} \mathrm{C}$, under $5 \% \mathrm{CO}_{2}$ conditions, in RPMI 1640 medium (Gibco-BRL ${ }^{\circledR}$, Gaithersburg, MO, USA) supplemented with $10 \%$ fetal bovine serum (PharmAust, Bentley, Western Australia), $1 \mathrm{mM}$ L-glutamine, 100 units $/ \mathrm{mL}$ penicillin, and $10 \mu \mathrm{g} / \mathrm{mL}$ streptomycin (Gibco). They were activated with $100 \mathrm{ng} / \mathrm{mL}$ of phorbol 12-myristrate 13-acetate (Gibco) and $1 \mu \mathrm{g} / \mathrm{mL}$ ionomycin (Sig$\mathrm{ma}$ ). The mononuclear cells were stained with anti-CD3 PerCP (anti-CD154 PE or anti-ICOS PE) and 
Table 2. Clinical and laboratory data of patients with $\mathrm{X}$ chromosome-linked agammaglobulinemia

\begin{tabular}{|c|c|c|c|c|c|c|c|c|c|}
\hline \multirow[t]{2}{*}{ Patient } & \multirow{2}{*}{$\begin{array}{c}\text { Hospital } \\
\text { admissions (n) }\end{array}$} & \multirow{2}{*}{$\begin{array}{c}\text { Pneumonias } \\
\text { (n) }\end{array}$} & \multirow{2}{*}{$\begin{array}{l}\text { Sinusitis } \\
\text { (n) }\end{array}$} & \multirow{2}{*}{$\begin{array}{c}\text { Otitis } \\
\text { media (n) }\end{array}$} & \multirow{2}{*}{$\begin{array}{c}\text { Diarrhea } \\
\text { episodes }(n)\end{array}$} & $\lg G$ & $\lg M$ & $\lg A$ & B cell \% \\
\hline & & & & & & $\begin{array}{c}(486-1211 \\
\mathrm{mg} / \mathrm{dL})\end{array}$ & $\begin{array}{l}(45-211 \\
\mathrm{mg} / \mathrm{dL})\end{array}$ & $\begin{array}{l}(30-182 \\
\mathrm{mg} / \mathrm{dL})\end{array}$ & $(19 \pm 8)$ \\
\hline P1 & 6 & 6 & 2 & 10 & 0 & 6.2 & 14.2 & 0.5 & 0 \\
\hline P2 & 4 & 0 & 0 & 0 & 0 & 28 & 6 & 11 & 0.12 \\
\hline P3 & 6 & 0 & 20 & 1 & 0 & 27 & 12 & 0.3 & 0 \\
\hline P4 & 2 & 0 & 0 & 0 & Several & 6.6 & 16.8 & 22.1 & 0.1 \\
\hline P5 & 1 & 1 & 0 & 0 & 0 & 6.7 & 17 & 23.4 & 0 \\
\hline P6 & 1 & 0 & 0 & 0 & 0 & 33.3 & 4.1 & 6.6 & 0 \\
\hline P7 & 1 & 6 & 0 & 0 & 0 & 6.6 & 17 & 1.5 & 0 \\
\hline P8 & 2 & 1 & 4 & 1 & 1 & 0 & 6 & 0 & 0 \\
\hline P9 & 1 & 1 & 0 & 0 & 0 & 41 & 8.6 & 6.7 & 0.3 \\
\hline P10 & 2 & 1 & 0 & 0 & 1 & 47.7 & 24.1 & 11.5 & 0 \\
\hline
\end{tabular}

anti-CD69 FITC. Incubation, washing and fixation were carried out as described.

Non-activated cells were used as negative controls and CD69 expression as positive control. The analysis is described later on.

\section{Acquisition and analysis}

For the analysis of peripheral blood leukocyte populations, 10,000 cells were observed and 100,000 were examined for mononuclear cell staining. The samples were read on the FACScalibur ${ }^{\circledR}$ platform. Data were examined using the FlowJo 10.0.07 software.

\section{Statistical analysis}

Demographic, clinical and laboratory data are indicated as medians and ranges or means and standard deviations, depending on the type of distribution; categorical variables, with frequencies and percentages. Patient phenotype is described with frequencies and percentages. The comparisons between both groups were made using Mann-Whitney's test. The results are expressed as the mean; values with $p<0.05$ were considered significant. Statistical analyses were performed using GraphPad Prism version 5.0.

\section{Results}

Table 2 summarizes the clinical and laboratory findings of 10 patients diagnosed with $\mathrm{XLA}$; serum immunoglobulin residual values and clinical data, both of the number of hospitalizations and infections, can be appreciated. Serum immunoglobulin values were correlated with B lymphocytes reduction.

Figure 1 shows representative results of one patient with XLA who showed a severe decrease in CD19+ B lymphocytes. To ensure that this cell population was absent, labeling with anti-CD20 was used, which confirmed the result. To corroborate the defect, BTK expression was analyzed; in no patient could this protein be identified (data not shown).

Figure 2 shows the results of CD19+ B lymphocyte staining, supplemented with $\operatorname{lgD}$ and CD27 staining. Both markers allow to define three subpopulations: naïve $B$ lymphocytes (IgD+CD27-), memory B cells without isotype change $(\lg D+C D 27+)$ and $B$ cells with isotype change (IgD- CD27+). In patients with hyper-lgM syndrome, although $B$ lymphocyte values were normal, an important decrease was observed in memory B lymphocytes (with and without isotype change); the diagnosis can be corroborated by the absence of CD154 in activated T lymphocytes and by efficient activation in T cells through CD69 expression. The graphs on the right side show the overall results of seven patients with hyper-IgM syndrome, in comparison with those obtained in the control subjects.

Figure 3 shows the staining of the B lymphocyte subpopulations, which allowed classifying patients with CVID. No patient exhibited agammaglobulinemia and CD40 and CD154 expression was normal. For the 
HC
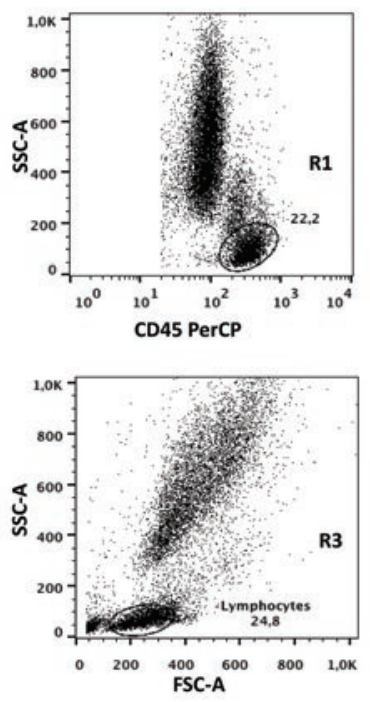
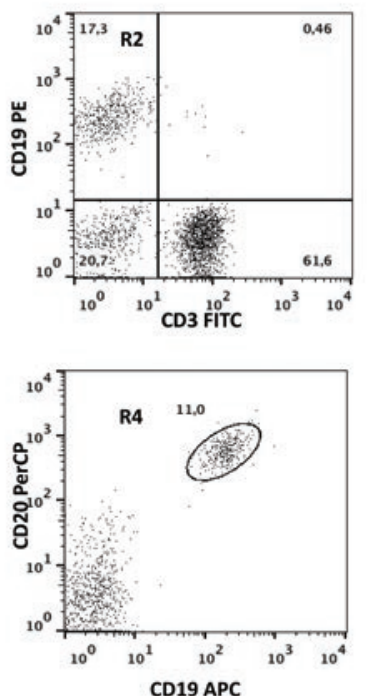

XLA
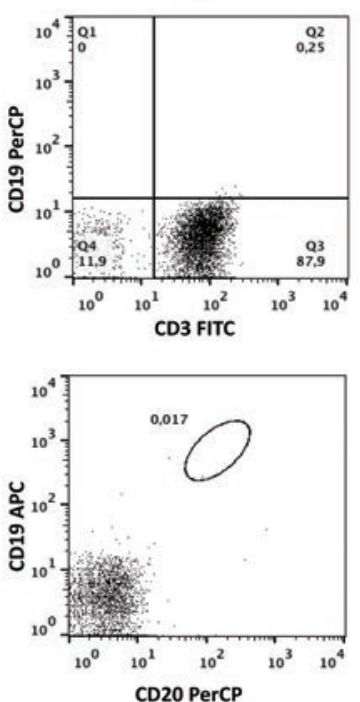

Figure 1. Flow cytometry results in patients with X-linked agammaglobulinemia (XLA). B cells were identified with CD45+ (R1) and CD19+ (R2). $C D 20+(R 3)$ and $C D 19+(R 4)$ expression is observed in the total lymphocyte region. $H C=$ healthy control.

HC

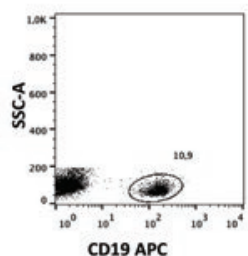

CD19 APC
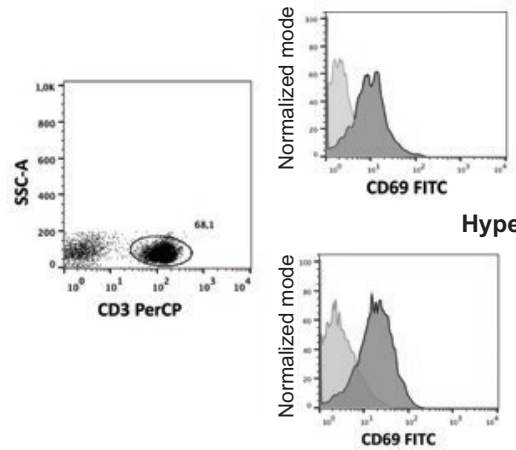

Hyper-IgM

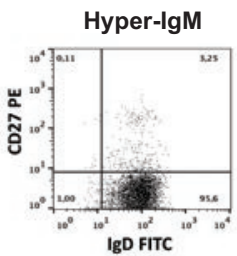

elathy Controls
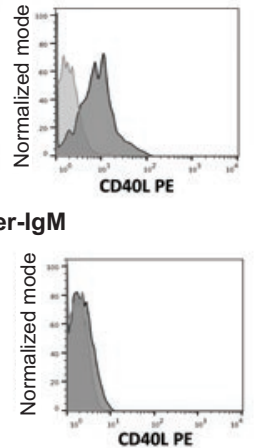
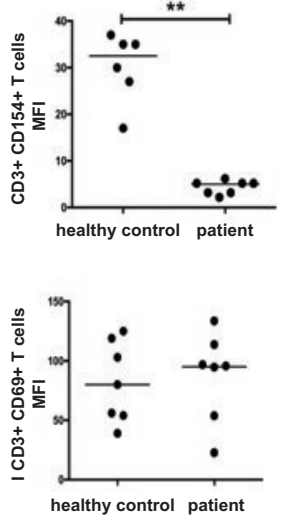

Figure 2. Analysis of patients with hyper-IgM syndrome. B cell subpopulations were identified with antibodies against CD19, CD27 and IgD, and CD154 and CD69 expression in the CD3+ T-cell region. The light gray histogram represents non-stimulated T cells and the dark gray histogram represents cells stimulated for 12 hours with ionomycin and phorbol 12-myristrate 13-acetate. CD154 (CD40L) and CD69 (activation control) expression can be observed in seven healthy controls and seven patients with hyper-IgM syndrome, as well as their respective values in mean fluorescence intensity (MFI). The horizontal bar shows the median, and the asterisks, significant differences using Mann-Whitney's $U$ statistical test. ${ }^{* *}$ Highly significant, $p<0.01$.

naïve $B$ cells, with and without isotype change, $\lg D+$ CD27 staining was used. Subpopulations with low CD21 expression (CD19+ CD21- CD38-) were also identified.
The patients were stratified according to the Freiburg classification:

- Group I, patients with reduced values (<0.4\%) of memory B lymphocytes with isotype change; 


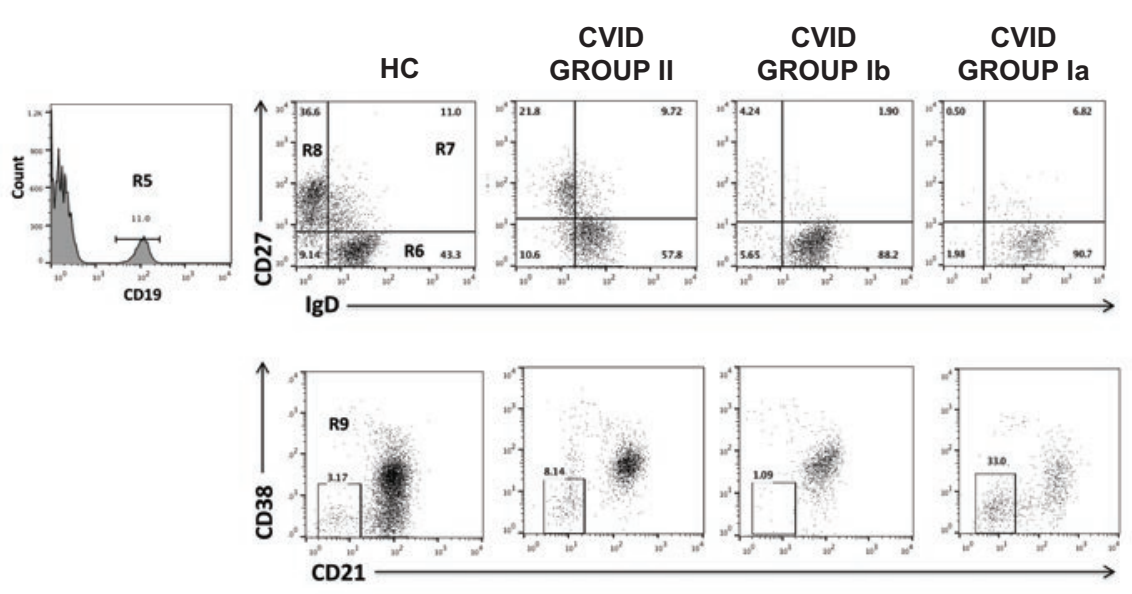

Figure 3. Analysis of patients with common variable immunodeficiency (CVID). B cells are identified with CD19+ (R5) and then subdivided as follows: Naïve B cells are identified with CD19+CD27- IgD+ (R6); B cells without isotype change or marginal zone, with $C D 19+C D 27+\lg D+(R 7)$; $B$ cells with isotype change, with $C D 19+C D 27+\lg D-(R 8) ; C D 21^{10 w} B$ cells, with CD19+CD21-CD38- (R9). Patients were stratified in groups la, $\mathrm{Ib}$ and II according to the Freiburg classification.

Table 3. Clinical and laboratory data of patients with common variable immunodeficiency, grouped according to the Freiburg classification

\begin{tabular}{|c|c|c|c|c|c|c|}
\hline Characteristic & \multicolumn{2}{|c|}{$\begin{array}{l}\text { Group la } \\
(n=10)\end{array}$} & \multicolumn{2}{|c|}{$\begin{array}{l}\text { Group Ib } \\
(n=10)\end{array}$} & \multicolumn{2}{|c|}{$\begin{array}{l}\text { Group II } \\
(n=4)\end{array}$} \\
\hline Female/male gender & \multicolumn{2}{|c|}{$7 / 3$} & \multicolumn{2}{|c|}{$7 / 3$} & \multicolumn{2}{|c|}{$3 / 1$} \\
\hline & \multicolumn{2}{|c|}{ Mean } & \multicolumn{2}{|c|}{ Mean } & \multicolumn{2}{|c|}{ Mean } \\
\hline Age (years) & \multicolumn{2}{|c|}{14.3} & \multicolumn{2}{|c|}{15.2} & \multicolumn{2}{|c|}{10.2} \\
\hline $\lg G(\mathrm{mg} / \mathrm{dL})$ & \multicolumn{2}{|c|}{210} & \multicolumn{2}{|c|}{213} & \multicolumn{2}{|c|}{243} \\
\hline $\lg \mathrm{A}(\mathrm{mg} / \mathrm{dL})$ & \multicolumn{2}{|c|}{27} & \multicolumn{2}{|c|}{18} & \multicolumn{2}{|c|}{27} \\
\hline $\operatorname{lgM}(\mathrm{mg} / \mathrm{dL})$ & \multicolumn{2}{|c|}{52} & \multicolumn{2}{|c|}{23} & \multicolumn{2}{|c|}{71} \\
\hline \multirow[t]{2}{*}{ B cells (\%) } & \multicolumn{2}{|c|}{9} & \multicolumn{2}{|c|}{11} & \multicolumn{2}{|c|}{17} \\
\hline & n & $\%$ & n & $\%$ & n & $\%$ \\
\hline Pneumonia & 5 & 50 & 6 & 60 & 2 & 50 \\
\hline Sinusitis & 6 & 60 & 5 & 50 & 1 & 25 \\
\hline Otitis media & 5 & 50 & 5 & 50 & 1 & 25 \\
\hline Chronic diarrhea & 2 & 20 & 3 & 30 & 0 & 0 \\
\hline Acute infectious gastroenteritis & 5 & 50 & 5 & 50 & 0 & 0 \\
\hline Autoimmune diseases & 5 & 50 & 2 & 20 & 0 & 0 \\
\hline Bronchiectasis & 5 & 50 & 4 & 40 & 1 & 25 \\
\hline Splenomegaly & 2 & 20 & 1 & 10 & 0 & 0 \\
\hline Lymphadenopathies & 4 & 40 & 1 & 10 & 0 & 0 \\
\hline
\end{tabular}

this group is subdivided in patients with an increased percentage ( $>20 \%$ ) of CD21 ${ }^{\text {low }} \mathrm{B}$ cells (group 1a) and patients with CD21 1ow cells normal expression (group 1b).
- Group II, patients with normal values of memory B lymphocytes with isotype change.

As detailed in Table 3, patients in group II showed moderate characteristics of the disease. In group I, a clear separation was observed when the presence of autoimmune diseases and lymphadenopathies were analyzed in patients with CD21 reduced expression.

\section{Discussion}

$\mathrm{XLA}$ is the result of mutations in the BTK gene, which is essential in the development of B cells. ${ }^{9}$ BTK is also expressed in peripheral blood monocytes; their search by cytometry yielded negative results in all patients with XLA (data not shown). Patients with XLA appear to have exacerbated inflammatory responses. Our group has proposed that BTK regulates the inflammatory response of monocytes, macrophages and polymorphonuclear cells. ${ }^{10}$

Patients with hyper-IgM syndrome are susceptible to opportunistic germs, they experience neutropenia, and some may develop autoimmune diseases and cancer. ${ }^{11}$ $B$ cells of these patients are unable to form germ centers and change isotype. The patients exhibit a decrease or frank absence of memory B cells, ${ }^{11}$ a condition that was verified in all the patients in this cohort. The most common defect was the absence of CD154 in activated T cells, ${ }^{12}$ a result that was obtained in all seven patients with hyper-IgM syndrome of this cohort.

Since the description of CVID in 1953, ${ }^{13}$ its complexity became relevant. Patients have highly diverse 
clinical manifestations, the severity of which is varied. The mutations that cause CVID phenotypes are observed in less than $20 \%$ of patients. Several research groups have stratified patients with CVID..$^{14-16}$ In this work, we used the Freiburg classification. Group la patients are those with the lowest total B cell expression in peripheral blood, in addition to experiencing the most serious clinical manifestations.

Through the use of flow cytometry, it was possible to diagnose XLA, hyper-IgM syndrome and CVID, which are conditions that involve a decrease or absence of antibody production. The diagnosis was obtained with a high level of reliability and will be able to guide the search for candidate genes with possible defects.

\section{Conflict of interests}

None.

\section{Funding sources}

This work was supported by Consejo Nacional de Ciencia y Tecnología: PDCPN 2015, project 900, granted to Leopoldo Santos-Argumedo, and project CB 2556471, granted to Laura Berrón-Ruiz.

\section{Ethical disclosures}

Protection of people and animals. The authors declare that the procedures followed adhered to the ethical standards of the responsible human experimentation committee and were in accordance with the World Medical Association and the Declaration of Helsinki.

Confidentiality of data. The authors declare that they have followed the protocols of their work center regarding the publication of patient data.
Right to privacy and informed consent. The authors have obtained the informed consent of the patients and/or subjects referred to in the article. This document is in the possession of the corresponding author.

\section{References}

1. McCusker C, Upton J, Warrington R. Primary immunodeficiency. Allergy Asthma Clin Immunol. 2018;14:61.

2. Bousfiha A, Jeddane L, Picard C, Ailal F, Bobby-Gaspar H, Al-Herz W, et al. The 2017 IUIS phenotypic classification for primary immunodeficiencies. J Clin Immunol. 2018;38:129-143.

3. Schatorjé EJH, Gathmann B, van Hout RWNM, de Vries E, Alsina L, Baumann $U$, et al. The PedPAD study: boys predominate in the hypogammaglobulinaemia registry of the ESID online database. Clin Exp Immunol. 2014;176:387-393.

4. Errante PR, Franco L, Espinosa-Rosales FJ, Condino-Neto A. Advances in primary immunodeficiency diseases in Latin America: epidemiology, research, and perspectives. Ann N Y Acad Sci. 2012;1250:62-72.

5. Smith T, Cunningham-Rundles C. Human immunology primary B-cell immunodeficiencies. Hum Immunol. 2019;80:351-362.

6. Mundy J, Sullivan T, Smith W, Kette F, Smith A, Heddle R, et al. Utility of peripheral blood $B$ cell subsets analysis in common variable immunodeficiency. Clin Exp Immunol. 2012;167:275-281.

7. Kanegane H, Hoshino A, Okano T, Yasumi T, Wada T, Takada H, et al. Flow cytometry-based diagnosis of primary immunodeficiency diseases. Allergol Int. 2018;67:43-54

8. Conley ME, Notarangelo LD, Etzioni A. Diagnostic criteria for primary immunodeficiencies (Pan-American Group for Immunodeficiency) and ESID (European Society for Immunodeficiencies). Clin Immunol. 1999;93:190-197.

9. Winkelstein JA, Marino MC, Lederman HM, Jones SM, Sullivan K, Burks AW, et al. X-linked agammaglobulinemia. Medicine (Baltimore). 2006;85:193-202.

10. González-Serrano ME, Estrada-García I, Mogica-Martínez D, González-Garay A, López-Herrera G, Berrón-Ruiz L, et al. Increased pro-inflammatory cytokine production after lipopolysaccharide stimulation in patients with X-linked agammaglobulinemia. J Clin Immunol. 2012;32:967-974.

11. Durandy A, Revy P, Imai K, Fischer A. Hyper-immunoglobulin M syndromes caused by intrinsic B-lymphocyte defects. Immunol Rev. 2005;203:67-79.

12. Qamar N, Fuleihan RL. The hyper IgM syndromes. Clin Rev Allergy Immunol. 2014;46:120-130

13. Janeway C, Apt L, Gitlin D. Agammaglobulinemia. Trans Assoc Am Physicians. 1953;66:200-202

14. Warnatz K, Denz A, Dräger R, Braun M, Groth C, Wolff-Vorbeck G, et al Severe deficiency of switched memory B cells (CD27+lgM-lgD-) in subgroups of patients with common variable immunodeficiency: a new approach to classify a heterogeneous disease. Blood. 2002:99:1544-1551.

15. Piqueras B, Lavenu-Bombled C, Galicier L, Bergeron-van der Cruyssen $F$, Mouthon L, Debré $P$, et al. Common variable immunodeficiency patient classification based on impaired $\mathrm{B}$ cell memory differentiation correlates with clinical aspects. J Clin Immunol. 2003;23:385-400.

16. Wehr C, Kivioja T, Schmitt C, Ferry B, Witte T, Eren E, et al. The EUROclass trial : defining subgroups in common variable immunodeficiency. Blood. 2008;111:77-85. 